\title{
The Tudor Monarchy of Counsel and the Growth of Reason of State
}

\author{
Joanne Paul with Valerie Schutte
}

There is a curious paradox in scholarly understandings of counsel during the Tudor period. On the one hand, political counsel is widely recognised to have been one of the central, if not the central, political concern of the Tudor period, as evidenced by its significance in texts such as More's Utopia, Elyot's Boke Called the Governor, Bacon's Essays and so on. ${ }^{1}$ On the other hand, the two longest-reigning and best-known monarchs of the period, Henry VIII and Elizabeth I, have a reputation - then and now - for being notoriously difficult to counsel, for refusing advice or being offended by the presentation of it. ${ }^{2}$ To add further complexity, both Henry VIII and his daughter Elizabeth were products of a humanist education which stressed the importance of counsel to a monarch, and went to great lengths to appear as if they were recipients of educated advice. ${ }^{3}$

Thus, teasing out the relationship between counsel and the Tudor crown is not easy, but it is essential to understanding both the way in which counsel influenced sovereignty in the early modern period as well as the political operations of the Tudor regime. This chapter will provide an outline of the discourse of counsel during the Tudor 'monarchy of counsel', before examining in particular the fundamental shift from a 'humanist' discourse of counsel in the early decades of the sixteenth century to a 'Machiavellian' discourse from the middle of the century. ${ }^{4}$ It will examine how this latter vocabulary became the foundation of the Reason of State tradition, which emphasises the prioritization the 'interest', of the state, often over more moral or religious considerations. ${ }^{5}$ These shifts are especially visible in the English, as opposed to European, context where the rule of a minor and two women in the second half of the sixteenth century shifted attention (and suspicion) onto the figure of the counsellor in a more 
explicit way than on the continent. The bulk of the chapter will thus focus on the Elizabethan discourse of Reason of State and how it fundamentally changed political counsel in this period.

\section{Studying the English Discourse of Counsel}

The 'discourse', 'problem' and 'paradox' of counsel in England during the 'monarchy of counsel' (from the end of the Wars of the Roses to the English Civil War) have received noteworthy attention of late, though significant gaps still exist in the literature. As John Watts has suggested, 'much more attention has been given to the growth of central government, the functioning of clientage networks, the changing structures of political society and the securing of compliance' than to counsel, but the study of the 'problem of counsel' has been revived in large part because of the generation of what John Guy has called the 'new political history' of Tudor England. ${ }^{6}$ Guy was the first to attempt a categorisation of two 'vocabularies' of the 'rhetoric of counsel': 'feudal-baronial' and 'humanist-classical', noting especially how they arose under the reign of Henry VIII. ${ }^{7}$ Even more recently, attempts to understand the 'monarchy of counsel' have been led by Jacqueline Rose, whose article on 'Kingship and Counsel in Early Modern England' added a third vocabulary to Guy's two, an 'exclusively religious' language of counsel. ${ }^{8}$

Work has also been done on counsel in particular Tudor regimes, though little has been done to compare and contrast across them. Perhaps the least explored is that of Henry VII, though work has been done on the changes he made to institutional councils during his reign, for instance by Peter Holmes, as well as Stephen Gunn, who has also drawn attention to the role of 'new men' within court and council. ${ }^{9}$ The complexities and brevity of Edwardian and Marian rule often mean that counsel is overlooked, though Stephen Alford has explored the theme in his Kingship and Politics in the Reign of Edward VI, and Joanne Paul has recently attempted to draw out some of the negotiations surrounding counsel in the reign of Mary I, 
from under the shadow of her half-sister's reign. ${ }^{10}$ These reigns are often passed over in favour of the more widely-studied Tudor monarchs: Henry VIII and Elizabeth I.

Studies of counsel under Henry VIII tend to focus on particular writings, such as those of Thomas More, ${ }^{11}$ Thomas Elyot, ${ }^{12}$ or Thomas Starkey. ${ }^{13}$ They often, too, isolate the role of councils, such as the Privy Council or parliament, ${ }^{14}$ or the roles of various fora for counsel, such as plays or poetry. ${ }^{15}$ Guy has especially noted the vocabularies and strategies of counsel in this period, ${ }^{16}$ and Richard Rex has shown how Henry VIII used counsel as a means to consensus following the break with Rome. ${ }^{17}$ The consensus is that humanism dominated Henrician expectations surrounding counsel-giving, which emphasised the virtue of both counsellor and monarch.

Commentary on counsel in the reign of the final Tudor monarch, Elizabeth I, contains far less consensus and remains more of a developing field than which examines her father's reign. Generally, however, and as one might expect, it has focused on the issue of gender. Anne McLaren, in particular, has drawn attention to the way in which Elizabeth's gender, combined with humanist expectations regarding counsel, generated the need for a strong mixed monarchy and 'queen-in-parliament' model of rule. ${ }^{18}$ Natalie Mears, contrastingly, focuses on the personal, rather than institutional, relationships and mechanisms of counsel, ${ }^{19}$ and recently Susan Doran has argued against the widely-held belief that Elizabeth and her counsellors were constantly at opposition, fighting over the reins of power. ${ }^{20}$ None of these accounts take seriously the context of Machiavellianism and the development of Reason of State under Elizabeth I. ${ }^{21}$ This chapter attempts to remedy this omission, by focusing on changes in discourse and vocabularies in the discourse of counsel in the Elizabethan period in comparison with those that had existed previously.

\section{Changing Discourses of Counsel}


By the early modern period, political counsel had been a part of European political thinking since its earliest days in ancient Greece and was an essential part of medieval political discourse. ${ }^{22}$ Medieval theory had placed the responsibility of giving counsel into the hands of the politically disengaged philosopher - Aristotle serving as the model ${ }^{23}$ - as well as the political right of the noble class, as a means of ensuring that they were given a voice in the decisions of the state. ${ }^{24}$ When this right was not respected, monarchs could be justifiably overthrown, as was the case with Richard II - Richard the 'redeless' (or adviceless) - in England in $1399 .^{25}$

With the spread of Renaissance humanism, philosopher was combined with courtier in crafting a new kind of counsellor who tempered truthful advice with an awareness of circumstance, as evidenced in Baldassare Castiglione's Book of the Courtier (1528). Such a courtier-counsellor ought to combine 'knoweleage of the truth' with 'Courtliness' so 'In the wise maye he leade [the prince], throughe the toughe way of vertue (as it were) deckynge yt aout with boowes to shadowe yt and strawinge it over wyth sightlye flouers' ${ }^{26}$ A similar sentiment is expressed in Thomas More's Utopia (1516), through the character of Morus, who recommends an 'indirect approach' and a 'more civil philosophy' (philosophia ciuilior $)^{27}$ 'that takes its cue, adapts itself to the drama in hand and acts its part neatly and appropriately' or 'cum decoro'. ${ }^{28}$

By the middle of the sixteenth century, however, such a figure became the object of deep suspicion. The reason was the rise of Machiavellianism - a political perspective based on, though not always faithful to, the writings of Niccolò Machiavelli, primarily The Prince (written 1513, published posthumously 1532). Machiavelli reversed the humanist model of counsel, in which the prince is 'led' or 'instructed' by the prudence of his counsellor(s), instead suggesting that the prince's prudence determines the wisdom of his council. ${ }^{29}$ Rhetoric, the 
tool of the humanist counsellor, was especially distrusted for its ability to 'move' or manipulate the emotions of the hearer, as in such a case, who truly ruled: prince or counsellor? For this reason, the middle of the century onwards saw an increase in the recommendation of books of history as counsellors (or counsellors who simply related the lessons of such books). Hence the popular maxim 'the best counsellors are the dead' for 'the penne is of a more free condition then the tongue'. ${ }^{30}$

In the later sixteenth century the rise of Reason of State literature, a phenomenon first described in print by Giovanni Botero in 1589, meant that the attention shifted to the 'observations' of neighbouring states - their geographical positions, policies and 'interests' with the aim of advancing one's own state interest over that of the others. ${ }^{31}$ It was, in short, a far cry from the virtuous courtiers of the humanist tradition and begins to look much more like the realist political 'science' of the modern period.

These tendencies were seen across Europe, but were especially felt in England where the discourse of counsel took on a particular importance. ${ }^{32}$ As has been noted, from the end of the Wars of Roses to the English Civil War, counsel was such a fundamental part of English political discourse that the regime has been identified as a 'monarchy of counsel' ${ }^{33}$ This is, of course, a contradiction in terms, as many throughout the sixteenth century realized, revealing the 'paradox of counsel' which defined relations between counsel and command in the period. If the counsellor, as in the humanist tradition, in fact knew better than the monarch, and led or governed him, then what was the role of a monarch at all? How could a monarch be truly said to be ruling?

These questions were latent during the reigns of Henry VII and Henry VIII. ${ }^{34}$ The 'tragedy of counsel' in this period encompassed not worries surrounding an overly-powerful counsellor, but rather increasing absolutism in the person of the monarch. Thus much of the literature struggled with how both to speak truth to a monarch (parrhesia) and keep one's head; 
a topic epitomized by both the writing and career of Thomas More, and known as the "problem of counsel'.

It is with the death of Henry VIII and the reign of his son, Edward VI, that attention and power shifts clearly onto the figure of the counsellor in the English court, along with a substantial level of suspicion. Importantly this moment coincides with the growth in the Machiavellian conciliar discourse noted above. Machiavelli's work circulated Europe, including in England, from the 1520s. In fact, of the small number of examples of articulated responses to Machiavelli in the first half of the sixteenth century, most address an English context, and the first attempts to apply his theories to political analysis were by English writers. ${ }^{35}$

This convergence of changed political reality - a minor on the throne, who was followed by two women - with changes in political discourse drew further attention to the role of the counsellor, though seldom in a positive way. Both minors and women were considered to be more easily influenced by adult male counsellors (as they lacked the prudence and rationality to rule over their counsellors or know good counsel from bad). ${ }^{36}$ At the same time, the prevalence of Machiavellian thought increased the perception of counsellors as selfinterested Machiavels who would all too willingly take advantage of such inferior rulers. ${ }^{37}$

\section{Queen Elizabeth I and Reason of State}

It was not just Elizabeth's gender which prompted significant changes to the means, content and significance of counsel during her reign, but also the confluence of factors, noted above, that dramatically altered the discourse of counsel in this period. ${ }^{38}$ Counsel in the reign of Elizabeth I became more 'practical' and outright, aiming at the preservation of the state, and less concerned with the virtue of monarch or subjects. Elizabethan counsellors were required 
by the expectations of the time to adapt to the goals and vocabularies of Reason of State as its primary agents.

Reason of State, as an idea, is notoriously difficult to pin down, which is why it seldom appears in scholarship on Elizabeth's reign. ${ }^{39}$ 'Reason of State', put succinctly, refers to the prioritization of the good, or 'interest', of the state, as well as the means to procure that end. As Botero defines it, it is 'the knowledge [notitia]' of such means by which a state, a 'firm rule over a people', may be 'found[ed], conserve[d] and expand[ed]'. ${ }^{40}$ Often it appears as the knowledge required to manage the state towards these ends in the absence of the laws and in extraordinary circumstances. ${ }^{41}$ It was this element especially which linked it to the role of the counsellor, who was often seen as the actor to provide guidance in circumstances which the laws did not cover, or in which they had to be contravened. ${ }^{42}$ In particular, this was often couched in the language of 'necessity' and 'occasion', the recognition that the good of the state required, in such emergency conditions, immoral or even unlawful action. ${ }^{43}$ It was the counsellors' job to recognize these exceptional moments, and act accordingly. ${ }^{44}$ These ideas defined the discourse of counsel under Elizabeth, in ways hitherto little explored.

From sixteenth-century accounts, we can pick out two distinct Reason of State traditions: 'Machiavellian' and 'Jesuit' ${ }^{45}$ The first develops from the spread of Machiavellian ideas from the 1530 s onwards. ${ }^{46}$ Central to Machiavellianism was the dissociation of utile and honestum - profit and honesty, often thought of as 'policy' and religion. ${ }^{47} \mathrm{~A}$ Machiavellian account accepted that the good of the state (or the prince) might be achieved through immoral or irreligious means, overturning the Ciceronian acceptance that morality and expediency went hand-in-hand. ${ }^{48}$ For instance, in the 1571 Treatise of Treasons, 'a Machiauellian State \& Regime[n]t' is 'where Religion is put behind in the seco[n]d \& last place: wher y' ciuil Policie... is preferred before it'. ${ }^{49}$ Botero agrees, suggesting that Machiavelli 'bases his Reason of State on lack of conscience'. ${ }^{50}$ 
The second, 'Jesuit', tradition seeks to oppose this Machiavellian discourse, advancing a 'true' Reason of State, which re-establishes the relationship between utile and honestum policy and religion - while retaining much of the vocabulary and framework of a Machiavellian account. This is the intention of the fallen Jesuit, Giovanni Botero, in the Della Ragione di Stato (1589), and is repeated in the work of the English priest and (after 1614) Jesuit, Thomas Fitzherbert, who seeks to compose 'some discourse concerning the necessarie concurrence of the reason of state with conscience and religion' ${ }^{51} \mathrm{We}$ might also turn to Fitzherbert's 'friend and mentor', and fellow Jesuit, Robert Persons (or Parsons), whose 1593 Newes from Spayne and Holland criticizes the 'councelles' of Lord Burghley for being lacking in 'iustice or co[n]science' as well as in 'humane wisdome and pollycy set downe by Machauel him selfe'. ${ }^{2}$ Persons demonstrates that it is 'a great ouersight in reason of state' for Elizabeth to have made 'so vniuersal a change of religion' by once again rejecting the Catholic religion. ${ }^{53}$ For Persons, Reason of State would have been aligned with God's will in steering Elizabeth to the restoration of the Catholic religion. Because they sought to oppose Machiavellian Reason of State in its own terms, these writers accepted some of its fundamental ideas. This significantly shifted expectations regarding how political counsel was given and received, and what it ought to contain.

The phrase 'Reason of State' appears seldom in Elizabethan political writing, despite Botero's assertions that Reason of State is 'mention[ed] nearly every day' in the 'courts of kings and great princes'. ${ }^{54}$ Given its immoral and irreligious associations, we may not be surprised. ${ }^{55}$ There are notable examples, however, which run counter to the prominent suggestion that it only permeates English political discourse in the mid-seventeenth century. ${ }^{56}$ In a letter ascribed to Francis Bacon from the 1580s, the author suggests that the queen ought to determine 'in all reason of state' what to do about the Catholics, who threaten her rule, noting he does not see how 'either in conscience' or 'in policy' she will be able to make them 
content. ${ }^{57}$ The Privy Council itself, in 1601, judges a matter to do with the Lord Mayer 'according to the reason of state and good government'. ${ }^{58}$ In short, by the end of Elizabeth's reign, Reason of State is present not only in published writings, such as those of Persons, but has entered into quotidian political parlance as well, albeit rarely.

More important than the term, however, are vocabularies and modes of political thinking associated with this new political discourse. Central to both Machiavellian and Jesuit Reason of State traditions was the emphasis on 'relations' or (later) 'observations': accounts of the 'situations' and affairs of other states. ${ }^{59}$ Such information provides the foundation for the politic scheming essential to working out how to secure the interest of one's own state. Botero's Relationi Universali, first published two years after his Ragione (1591-96) was an almanac of sorts, detailing the state of universal relations between states. There was no contemporary English translation of the Ragione, but the Relationi went through seven print editions between 1601 and 1630, each time altered and updated to align with changing political realities and the interests of the translator. ${ }^{60}$

Even long before Botero, counsellors inspired by Machiavelli had begun to compile precisely these sorts of accounts. For instance, William Thomas's advice to Edward VI, composed sometime in late 1551, was heavily inspired by Machiavelli; when Edward can 'not plaie the Lyon' - i.e. to use overt force - Thomas tells him that 'it [is] no shame to plaie the Foxe' or, in other words, to 'worke by policie'. ${ }^{61}$ 'Policie', Thomas suggests, 'is no vice' and is unavoidable in 'these daies' when princes commonly employ such tactics. In another short piece by Thomas, 'My private opinion tooching your $\mathrm{Ma}[\mathrm{ies}]^{\text {ties }}$ outward affaires at this present', he gives detailed accounts of England's relations with various European nations, and the motives each nation has for various paths of action. ${ }^{62}$ Robert Beale composes a similar account in his Treatise of the Office of a Councellor and Principall Secretarie to her Ma[jes]tie, written in 1592. There, he recommends Thomas Smith's De Republica Anglorum 
for understanding 'the State of the whole Realme' (though in it 'ther be many defects'). ${ }^{63}$ This is not enough, however, and a secretary must also 'obtaine by dilligent readinge and observac[i] on of the histories of all Countryes' an understanding of the relationship between England and the nations with which it has dealings. ${ }^{64}$ In this, Beale is more detailed, because 'I would wish you to followe another course w[i]th them than hath beene of maie yeares heretofore used. ${ }^{65}$ Some have even 'despised' this knowledge, so that the Queen is 'not duelie informed how thinges passe, nor hath anye of her subiects so acquainted w[i]th forraine affaires as is fitt for her Ma[jes]tie's service. ${ }^{66}$ The remedy? The secretary ought to have on hand 'your Italian Relationi', Botero's text, which 'may stande you in some steede for the knowledge of forraigne Estates' ${ }^{67}$

Beale's specific advice about affairs with other nations is rife with the language of Reason of State. In particular, Beale suggests - in reference to dealing with the Italians - ' $c u m$ Cretensibus Cretisandum est', a phrase that also appears in a letter by Burghley from 1593: 'cretisare cum cretensi' or 'to deceive among deceivers', which he says is 'allowable'. ${ }^{68}$ The phrase also appears in an earlier 1580 letter to Burghley from Thomas Radcliff, Earl of Sussex, who worries that the French 'cretizare cum cretensibus', assuming that the English are deceiving them. Like Thomas and others, Beale has accepted the necessity of occasional deception, to the end of preserving the state. ${ }^{69}$

Whereas appearances of the phrase 'Reason of State' and references to Botero's Relationi, or writings like it, are scattered, the language of 'necessity', 'occasion' and 'temporizing' is ubiquitous. These ideas, it should be said, were not new in the mid-sixteenth century. The vocabulary of 'occasion' complete with its immoral and exceptional associations comes from the ancient concept, kairos, or 'the opportune moment', which had appeared in the works of various classical thinkers, including Plato, Isocrates and Plutarch, and was revived in the Renaissance. ${ }^{70}$ The idea that such opportune moments must not be 'let slip', or else the 
state would face dangerous threats, appears in political discourse of the fifteenth century and early sixteenth centuries, but by the mid-sixteenth century had acquired an air of greater deception and urgency, as well as appearing more frequently. In 1549, under the reign of the young Edward VI, William Paget especially connected such language to the role of counsellors, telling Thomas Smith that 'Wherefore whenne princes be in saden [sudden] heates, and specially without certaine ground, we Secretaries must temporise the matter $\mathrm{w}^{\mathrm{t}}$ termes convenient. $^{, 71}$

By the reign of Elizabeth, this language was pervasive. John Challoner writes to William Cecil twice in November 1559, urging him to remind the queen not to lose the 'occasion' and that 'It is good to remember that occasion serves not alwaye'. ${ }^{72}$ It is important, these letters make clear, to take advantage of opportunity when England has it, before it shifts to England's enemies; as Ambrose Dudley, Earl of Warwick and Amias Poulet, ambassador to France, write to Robert Dudley and Cecil in 1563, 'leaving the good occasion p[re]sently offered, [Elizabeth] wold seme to kepe peace towards theym $\mathrm{w}^{\text {ho }}$ will not faile to make her as extreme... warre as they can[n] devise as sone as they shall se the tyme off [sic] advantage. ${ }^{73}$ Poulet writes again to Burghley in 1578, hoping that the queen is aware of this temporizing game: 'I hope her ma[jes]tie is to well acquainted w[i]th the Spaniarde to be abused w[i]th his Rhethoricke, and yt behoveth us to knowe that the loss of a daye is of greate moment in these actions. The Spaniarde knoweth yt, and therefore sekyth to wynne tyme by all meanes possible, and when his turne is served, he maye $\mathrm{p}$ [er]chance turne his flatteries into threatenings. ${ }^{74}$ Elizabeth will never escape the 'malice and cruelty' of the Spanish unless she 'make her profytt of gudde blessings, I meane [inserted: of] the tyme when it serveth, and of occasions when they are profered. ${ }^{, 75}$

There also exists, however, a recognition that these games of opportunity are not enough. In regards Elizabeth's opposition to Anjou over the lordship of the Low Countries, in 
which she had asked her ambassadors to use ‘delays' against Anjou until English forces arrive, Thomas Wilson writes that 'Temporysinge hath been thought heretofore good policie', but 'There was never so da[n]gorouse a tyme as this is, and temporizinge wil no longer serue' ${ }^{76}$ Instead, he is glad to see that Elizabeth is now considering 'preventi[n]g against da[n]ger to be feared' ${ }^{77}$ In particular, this prevention needed to be taken against those who would seize their own opportunities against the English crown.

This language of emergency and pre-emption is clearest in the discussion of what is to be done about Mary Queen of Scots. In 1572, reasons were laid out in the House of Commons why Elizabeth was 'bound in Conscience to proceed with Severity' against Mary, which urged Elizabeth that a new law would not be enough, as 'no Law hath any force with her' as she is 'fully minded to take her advantage upon any apt occasion offered. ${ }^{78}$ The willingness to seize occasion, regardless of morality and law, means these are not enough to bind someone; extralegal measures must be embraced. In a 1587 document titled 'A discourse plainlie proveinge that as well the sentence of death latelie given against that unfortunate ladie Marie late Queene of Scotts as also the execution of the same sentence were honourable just necessarie and lawfull', the author stresses that the spread of the 'disease' presented by the threat of Mary became 'dailie more and more desperate' and so there could be no longer any 'delay'. ${ }^{79}$ For Elizabeth's part, the author suggests she wishes 'the occasion had never bene given' to overcome Mary, and that 'the regarde of state' (a rendering of Reason of State) 'and regall administration were not so great and obligatory... as in troth they be' ${ }^{80}$ Princes, he makes clear, follow different rules than do private individuals, for they are bound by 'their office and dutie of administration' and the 'Case of the Commonwealth', in which they are guided by 'all the wiser Iudgements of the Realme and the three estates assembled in full Parliament' ${ }^{81}$ Every other prince, he maintains would have done the same, with 'the oportunitie so well serving for 
that purpose', 'even when no necessitie of the state or $\mathrm{p}$ [er]ill of the Prince of that dominion inforced, as nowe it did'. ${ }^{82}$

Elizabeth's decision was 'expedient in all good pollicy' and her reputation would have suffered had she done otherwise, for 'all great Princes and governors are then thought wisest and most worthie of their Administration when they be vigilant and lett not slipp any good and honest advantage offered them'. ${ }^{83}$ In fact, he goes on, Elizabeth, by 'exacte pollicie' might even be expected to seek the life of the young King James VI, but 'as a most Christian and vertuous Princesse utterly detesteth all such manner of Pollicie, and houldeth it in great horror and abhomination and all those that would $\mathrm{p}$ [re]sume to give her any such advice. ${ }^{84}$

The author argues that Elizabeth did proceed according to the law, and with the consent of parliament, though also suggests that she acted according to the "universall Consent and uniformitie of mans opinion and will', which 'thoughe it be not properlie a iustifying lawe' it is not 'altogether not a lawe', namely: 'rather to kill than be killed'. ${ }^{85}$ And another, that 'the greater good is $\mathrm{p}[\mathrm{re}]$ ferred befor the smaller, the generall before the speciall and the Cases of necessitie before those that be ${ }^{\wedge}$ not $^{\wedge}$ necessary. ${ }^{86}$ In short, Elizabeth, the author maintains, did act according to the law and expectations of honour, but she also acted in line with the expectations of Reason of State; this alone would have been enough to justify her actions, and indeed, worse ones.

The backdrop of Reason of State rendered Elizabeth's perceived ability - already limited by gender - to judge good counsel from bad more suspect, and thus increased the apparent power of the counsellor to benefit or destroy the realm. In response, Elizabeth used delay as a political tool against the demands of her counsellors, whose emphasis on seizing occasion often proceeded from frustration at Elizabeth's irresolution. In a political culture where her gender could give her the appearance of weakness in contrast to her male counsellors, Elizabeth used her own temporizing strategies to maintain power and control. 


\section{Conclusion}

Elizabeth's gender was certainly important in shaping the political culture of her reign, but there were other influences determining the nature of the discourse of counsel in the latter half of the sixteenth century. Reason of State introduced a new political language, as well as a new way of thinking about politics built on moral flexibility, the emphasis on inter-state relations and an awareness of opportunity, temporizing and necessity, even exceptionalism. This fundamentally altered the role of the counsellor and the content of political counsel in this period, with important implications for early modern political authority.

England saw a shift in councilliar strategies not only because of the rule of one minor and two women but also due in part to continental influences. The analysis of Elizabethan counsel offers a contribution to existing literature, by showing that Reason of State vocabularies were pervasive in Elizabethan politics. By the end of the sixteenth century, counsel had shifted from a rhetorical practice aimed at the achievement of virtue, to apparently straightforward (though sometimes still deceptively rhetorical) practical advice regarding the state 'interests'.

\footnotetext{
${ }^{1}$ See Thomas More, Utopia, ed. George M. Logan and Robert M. Adams (Cambridge: Cambridge University Press, 1989), 13-37; Thomas Elyot, The Book Named the Governor, ed. S. E. Lehmberg (New York: Everyman's Library, 1962), 13, 108, 236-41; Francis Bacon, Essaies (London, 1612), 56-69.

${ }^{2}$ For Henry VIII see below. See Christopher Haigh, Elizabeth I (London: Routledge, 2001), 200. Elizabeth's approach to receiving counsel is also evidenced in the history described by Raphael Holinshed, The First volume of the Chronicles of England, Scotlande, and Ireland (London, 1577), 1777.

${ }^{3}$ This was often accomplished through performance, see Greg Walker, The Politics of Performance in Early Renaissance Drama (Cambridge: Cambridge University Press, 1998), 67; W. R. Streitberger, The Masters of the Revels and Elizabeth I's Court Theatre (Oxford: Oxford University Press, 2016), 17, 78, 172; see also a number of contributions in the volume
} 
Jayne Elizabeth Archer, Elizabeth Goldring and Sarah Knight, eds, The Progresses, Pageants, and Entertainments of Queen Elizabeth I (Oxford: Oxford University Press, 2007), 4, 86, 90, 92, 99, 101-2.

${ }^{4}$ For the 'monarchy of counsel' see JGA Pocock, 'A Discourse of Sovereignty: Observations on the Work in Progress,' in Political Discourse in Early Modern Britain, ed. Nicholas Phillipson and Quentin Skinner (Cambridge: Cambridge University Press, 1993), 396.

${ }^{5}$ These categories are not without their problems. To juxtapose the 'humanist' and 'Machiavellian' perspectives on counsel seems to overlook the fact that Machiavelli, too, was a humanist. In addition, the 'Machiavellian' discourse of counsel often had very little to do with Machiavelli's own views. However, these titles are the best available to refer to these traditions, and thus will be adopted throughout this piece. More will be said about the definition of 'Reason of State' in what follows.

${ }^{6}$ John Watts, 'Counsel and the King's Council in England, c.1340-c.1540', in The Politics of Counsel in England and Scotland, 1286-1707, ed. Jacqueline Rose (Oxford: Oxford University Press, 2017), 63. The 'problem of counsel' was the subject of a number of studies in the 1950s-1970s: see Arthur B. Ferguson, 'The Problem of Counsel in Mum and the Sothsegger', Studies in the Renaissance 2 (1955): 67-83; Stanford E. Lehmberg, 'English Humanists, the Reformation, and the Problem of Counsel', Archiv Für

Reformationsgeschichte - Archive for Reformation History 52 (1961): 74-91; J. H. Hexter, 'Thomas More and the Problem of Counsel', in Quincentennial Essays on St. Thomas More: Selected Papers from the Thomas More College Conference (Boone: Albion, 1978), 55-66. For more on the 'new political history' of Tudor England see John Guy, Tudor Monarchy (London: Hodder Education Publishers, 1997), 1-8; Stephen Alford, 'Politics and Political History in the Tudor Century', The Historical Journal 42, no. 2 (1999): 535-48.

${ }^{7}$ John Guy, 'The Rhetoric of Counsel in Early Modern England', in Tudor Political Culture, ed. Dale Hoak (Cambridge: Cambridge University Press, 1995), 292-310. I will not be speaking according to these two 'languages', though my analysis falls primarily into Guys 'humanist-classical'. Guy also focuses, in terms of this vocabulary, on amicitia, which is not a focus of what follows here.

8 Jacqueline Rose, 'Kingship and Counsel in Early Modern England', The Historical Journal 54, no. 1 (2011): 47-71. Religion comes into various aspects of what I detail below, though the 'religious' language, as Rose details it, does not.

${ }^{9}$ Peter Holmes. 'The great council in the reign of Henry VII.' The English Historical Review 101, no. 401 (1986): 840-862; Stephen Gunn, Henry VII's New Men and the Making of Tudor England (Oxford: Oxford University Press, 2016).

${ }^{10}$ Stephen Alford, Kingship and Politics in the Reign of Edward VI (Cambridge: Cambridge University Press, 2004), 46-8, 63-4; Joanne Paul, 'Sovereign Council or Counseled Sovereign: The Marian Conciliar Compromise,' in The Birth of a Queen: Essays on the Quincentenary of Mary I, ed. Sarah Duncan and Valerie Schutte (New York: Palgrave, 2016), 135-53.

${ }^{11}$ J. H. Hexter, 'Thomas More and the Problem of Counsel', in Quincentennial Essays on St. Thomas More: Selected Papers from the Thomas More College Conference (Boone: Albion, 1978), 55-66; Ivan Lupic, 'Subjects of Advice: Drama and Counsel from More to Shakespeare' (PhD Diss, Columbia University, 2014).

${ }^{12}$ F.W. Conrad, 'A Preservative Against Tyranny: Sir Thomas Elyot and the Rhetoric of Counsel', in Reformation, Humanism, and 'Revolution': Papers Presented at the Folger Institute Seminar 'Political Thought in the Henrician Age, 1500-1550', ed. Gordon J. Schochet (Washington, D.C.: The Folger Institute, 1990), 191-206; F.W. Conrad, 'The Problem of Counsel Reconsidered: The Case of Sir Thomas Elyot', in Political Thought and the Tudor Commonwealth: Deep Structure, Discourse and Disguise, ed. Paul Fideler and 
Thomas Mayer (London: Routledge, 2003), 77-110;Arthur Walzer, 'Rhetoric of Counsel in Thomas Elyot's Pasquil the Playne', Rhetorica: A Journal of the History of Rhetoric 30, no. 1 (2012): 1-21; Arthur E. Walzer, 'The Rhetoric of Counsel and Thomas Elyot's Of the Knowledge Which Maketh a Wise Man', Philosophy and Rhetoric 45, no. 1 (2012): 24-45. ${ }^{13}$ Thomas F. Mayer, 'Thomas Starkey, an Unknown Conciliarist at the Court of Henry VIII', Journal of the History of Ideas 49, no. 2 (1988): 207-27; Thomas F. Mayer, 'Faction and Ideology: Thomas Starkey's Dialogue', The Historical Journal 28, no. 1 (1985): 1-25.

${ }^{14}$ G. R. Elton, The Tudor Revolution in Government (Cambridge; Cambridge University Press, 1953), pp 316-69.

${ }^{15}$ Greg Walker, Writing Under Tyranny: English Literature and the Henrician Reformation (Oxford: Oxford University Press, 2007); Greg Walker, Plays of Persuasion: Drama and Politics at the Court of Henry VIII (Cambridge: Cambridge University Press, 2009).

${ }^{16}$ John Guy, 'The Rhetoric of Counsel in Early Modern England', in Tudor Political Culture, ed. Dale Hoak (Cambridge: Cambridge University Press, 1995), 292-310; John Guy, 'Ideas of Counsel Under Henry VIII - The Tudors', accessed 25 October 2017, http://www.tudors.org/undergraduate/ideas-of-counsel-under-henry-viii/.

${ }^{17}$ Richard Rex, 'Councils, Counsel and Consensus in Henry VIII's Reformation', in The Politics of Counsel in England and Scotland, 1286-1707 (Oxford: British Academy, 2016),.

${ }^{18}$ A. N. McLaren, Political Culture Reign Elizabeth I: Queen and Commonwealth 1558-1585 (Cambridge: Cambridge University Press, 2004).

${ }^{19}$ Natalie Mears, Queenship and Political Discourse in the Elizabethan Realms (Cambridge University Press, 2005).

${ }^{20}$ Susan Doran, 'Elizabeth I and Counsel', in The Politics of Counsel in England and Scotland, 1286-1707, ed. Jacqueline Rose (Oxford: Oxford University Press, 2017), 151-61.

${ }^{21}$ The exception to this has been the recent Peter Lake, Bad Queen Bess?: Libels, Secret Histories, and the Politics of Publicity in the Reign of Queen Elizabeth I (Oxford, New York: Oxford University Press, 2016) which examines charges of Machiavellianism in a variety of Elizabethan libels and pamphlets.

${ }^{22}$ This summary is also given in Helen Matheson-Pollock and Joanne Paul, introduction to Queenship and Counsel in Early Modern Europe (New York: Palgrave), [forthcoming]. For a more detailed account of the changing discourse of counsel in the Early Modern period see Joanne Paul, 'Counsel and Command in Anglophone Political Thought, 1485-1651' (PhD diss., Queen Mary University of London, 2013).

${ }^{23}$ Best evidenced by the immensely popular Secretum Secretorum; see M. A. Manzalaoui, ed., Secretum Secretorum: Nine English Versions (Oxford: Oxford University Press, 1977), ix and Steven J. Williams, The Secret of Secrets: the Scholarly Career of a Pseudo-

Aristotelian Text in the Latin Middle Ages (Ann Arbor: University of Michigan Press, 2003), $10-28$.

${ }^{24}$ See Guy, 'The Rhetoric of Counsel in Early Modern England', 292-310.

25 James M. Dean, ed., Richard the Redeless and Mum and the Sothseggar (Kalamazoo:

Medieval Institute Publications, 2000).

${ }^{26}$ Baldassare Castiglione, The Book of the Courtier, trans. Thomas Hoby, ed. Virginia Cox (London: Everyman, 1994), 338, 299. Notably, Castiglione still holds Aristotle (as well as Plato) to be an example of such a counsellor. They both 'practiced the deedes of Courtiershippe and gave them selves to this ende, the one with the great Alexander, the other with the kynges of Sicilia' (337). This is opposed to Calisthenes, 'who bicause he was a right philosopher and so sharpe a minister of the bare truth without mynglinge it with Courtlinesse, he lost his lief and profited not, but rather gave a scaundler to Alexander' (338).

${ }^{27}$ My translation from Thomas More, Utopia, trans. and ed. Edward Surtz, J. H. Hexter (New Haven: Yale University Press, 1965), 99. 
${ }^{28}$ More, Utopia, 34-5.

${ }^{29}$ Niccolò Machiavelli, The Prince, ed. Quentin Skinner and Russell Price (Cambridge: Cambridge University Press, 1988), 82.

${ }^{30}$ Matthew Coignet, Politique discourses upon trueth and lying, trans. Edward Hoby (London, 1586), 69-70. See Joanne Paul, 'The best counsellors are the dead: counsel and Shakespeare's Hamlet,' Renaissance Studies 30.5 (2016): 646-65.

${ }^{31}$ Giovanni Botero, Botero: The Reason of State, ed. Robert Bireley (Cambridge, United Kingdom ; New York, NY: Cambridge University Press, 2017). More detail about this literature is given in what follows.

${ }^{32}$ See Guy, 'The Rhetoric of Counsel', 292-310; David Colclough, 'Parrhesia': the Rhetoric of Free Speech in Early Modern England,' Rhetorica 17.2 (1999): 177-212; Jacqueline Rose, 'Kingship and Counsel in Early Modern England', The Historical Journal 54.1 (2011): 4771; Janet Coleman, 'A Culture of Political Counsel: The Case of Fourteenth-Century England's 'Virtuous' Monarchy vs Royal Absolutism and Seventeenth-Century Reinterpretations' in Monarchy and Absolutism in Early Modern Europe, ed. Cesare Cuttica and Glenn Burgess (London: Pickering and Chatto, 2012), 19-31.

${ }^{33}$ Pocock 'A Discourse of Sovereignty', 396.

${ }^{34}$ In the case of a counsellor like Cardinal Wolsey, the fears surrounding his rise had less to do with the persuasive power of his rhetoric and more to do with his increasing direct political control.

${ }^{35}$ Sydney Anglo, Machiavelli - the First Century: Studies in Enthusiasm, Hostility and Tudor Politics in the Sixteenth Century (Oxford: Oxford University Press, 2005), 102.

${ }^{36}$ For women's perceived lack of prudence see Leah Bradshaw, 'Political Rule, Prudence and the "Woman Question" in Aristotle', Canadian Journal of Political Science 24.3 (1991): 56370. Partly, this was because they could not possibly have the political experience requisite for such a virtue - women end up excluded from politics because they had been excluded from politics - , but it also had to do with a long-standing tradition of seeing women's advice on many matters as irrational, self-interested and dangerous. For a contemporary commentary on women's inability to engage with political counsel see John Knox, The first blast of the trumpet against the monstruous regiment of women, (Geneva, J. Poullain and A. Rebul, 1558), 9-10. See also Misty Schieberle, Feminized Counsel and the Literature of Advice in England, 1380-1500, (Turnhout: Brepolis, 2014).

${ }^{37}$ See for instance Treatise of Treasons (Antwerp, 1572), fos. 86v, 86r; John Stubbe, Gaping Gulf, ed. Lloyd E. Berry (Charlottesville: University Press of Virginia, 1986), 12; Leicester's Commonwealth, ed. D. C. Peck (Athens, OH: Ohio University Press 1985), 132, 154. ${ }^{38}$ As described above.

${ }^{39}$ See Thomas M. Poole, Reason of State: Law, Prerogative and Empire (Cambridge: Cambridge University Press, 2015), 2-3 for the various meanings of 'Reason of State' across time and space. Notably, although he acknowledges its influence from the death of Machiavelli, his study begins in roughly 1650. Alessandro Arienzo, 'From Machiavellian Policy to Parliamentary Reason of State: Sketches in Early Stuart Political Culture' in Machiavellian Encounters in Tudor and Stuart England: Literary and Political Influences from the Reformation to the Restoration, ed. Alessandro Arienzo and Alessandra Petrina (London and New York: Routledge, 2013), ebook, focuses largely on Reason of State in the seventeenth century. Alexandra Gadja, 'Tacitus and Political Thought in Early Modern Europe, c. 1530-c. 1640', The Cambridge Companion to Tacitus, ed. A. J. Woodman (Cambridge: Cambridge University Press, 2009), 266 claims that 'there was no strong native equivalent of Continental 'reason of state' literature'. For the origins of the term, see Conal Condren, 'Reason of State and Sovereignty in Early Modern England: A Question of 
Ideology?', Parergon 28.2 (2011): 13; he too has little to say about Elizabethan politics and Reason of State.

${ }^{40}$ Botero 2017, 4, see fn. 2.

${ }^{41}$ David Tucker, The End of Intelligence: Espionage and State Power in the Information Age (Stanford: Stanford University Press, 2014), 27; Poole 2015, 3-4; see also Maurizio Viroli, From Politics to Reason of State: The Acquisition and Transformation of the Language of Politics, 1250-1600 (Cambridge: Cambridge University Press, 1992), 240-1.

${ }^{42}$ As Viroli 1992, 241 points out, within Reason of State logic, the only universal rule is to rely on experienced counsellors, who can advise on specific circumstances (and to rule justly).

${ }^{43}$ See Viroli 1992, 249; Condren 2011, 14.

${ }^{44}$ Paul 2013, 120-1, 131-3, 143, 145-6, 280-312.

45 This distinction between the two traditions is my own, though Arienzo 2013 points out that, in contrast to Machiavellianism, Reason of State could have a positive meaning 'distinguished from a false Machiavellian practice', thus allowing for the possibility of two different kinds of Reason of State: one negative and Machiavellian, the other positive and anti-Machiavellian.

${ }^{46}$ It is also, notably, associated with Tacitus. Work has been done on the influence of Tacitus on Elizabethan thought and politics, though not always with reference to Reason of State. See John Guy, The Reign of Elizabeth I: Court and Culture in the Last Decade (Cambridge: Cambridge University Press, 1995), 15-16; Gadja 2009, 266-7; Susan Doran, Elizabeth I and Her Circle (Oxford: Oxford University Press, 2015), 303-8.

${ }^{47}$ Arienzo 2013, ebook.

${ }^{48}$ See Treatise of Treaons (Antwerp, 1572), sig. a $5^{\mathrm{r}}$..

${ }^{49}$ [Leslie] 1572, sig. a5 ${ }^{\mathrm{r}}$. The book is anonymous, but is usually attributed to John Leslie, Bishop of Ross; see Ethan H. Shagan (2005). Catholics and the 'Protestant Nation': Religious Politics and Identity in Early Modern England, Manchester: Manchester University Press, 77.

${ }^{50}$ Botero 2017, 1. Of course, much of this is actually a misreading of Machiavelli's own work, but it is consistent with how it was read in the sixteenth century.

${ }^{51}$ Thomas Fitzherbert, The First Part of a Treatise Concerning Policy, and Religion (London, 1606). 36. See also Robert Persons, Newes from Spayne and Holland (London, 1593), 22 and Benjamin Carier, A Treatise (London, 1614), 30, 32.

${ }^{52}$ Persons 1593, 22; see Höpfl 2011, 94, 96.

${ }^{53}$ Persons 1593, 22. The later Catholic writer Benjamin Carier disagrees in his Treatise (1614), suggesting that 'it were necessary in reason of State' for Elizabeth to 'continue the Doctrine of Diuision' with Rome (as the daughter of Henry VIII and Anne Boleyn) (32). Reason of State and the true religion were, for a short time, indeed at odds. However, this no longer applies under James I, so Carier finds that Reason of State and the Catholic religion are realigned in his reign: he 'doe finde as little cause of holding out in reason of State, as I doe in truth of Doctrine' (30).

${ }^{54}$ Botero 2017, 1; See Condren 2011, 17-18.

${ }^{55}$ Viroli 1992, 252.

${ }^{56}$ See fn. 39 above.

57 [Francis Bacon?], '[Letter of Advice to Queen Elizabeth I]' in The Letters and Life of Francis Bacon, ed. James Spedding (London: Longman, Green, Longman, and Roberts, 1861), 47, 48. On Bacon and Reason of State see Vera Keller, 'Mining Tacitus: Secrets of Empire, Nature and Art in the Reason of State', BJHS 45.2 (2012): 189-212.

${ }^{58}$ PC 2/26 f.493, 1601.

${ }^{59}$ See Arienzo 2013; Keller 2012, 192. 
${ }^{60}$ See Joanne Paul and Kurosh Meshkat, 'Johnson's Relations: Visions of Global Order, 1601-1630', Journal of Intellectual History and Political Thought 1.1 (2013): 108-40.

${ }^{61}$ Thomas 1774, p. 136.

62 Thomas 1774, p. 179-92.

${ }^{63}$ Robert Beale, 'A Treatise of the Office of a Councellor and Principall Secretarie to her $\mathrm{Ma}[\mathrm{ies}]$ tie' in $\mathrm{Mr}$ Secretary Walsingham and the Policy of Queen Elizabeth, Vol I, ed. Conyers Read (Oxford: Clarendon Press, 1925), 428.

${ }^{64}$ Beale 1925, 433

${ }^{65}$ Beale 1925, 435

${ }^{66}$ Beale 1925, 435

${ }^{67}$ Beale 1925, 435

${ }^{68}$ Beale 1925, 434; Bughley to Robert Cecil 1593 in Wright, Thomas (1838). Queen Elizabeth and Her Times: a Series of Original Letters, Vol. II, London, 425. The Epimenides paradox depends on the deception of Cretans, and is repeated in St Paul's letter to Titus (1:12). Machiavelli sets out the necessity of deceiving amongst deceivers in Chapter XV of The Prince.

${ }^{69}$ See Francis Bacon (1861). Certain Observations Made Upon a Libel Published This Present Year, 1592 in The Letters and the Life of Francis Bacon, ed. James Spedding, Longman, Green, Longman and Roberts, London, 167-70; SP 59/10 f.42, Sept 15, 1565; SP 84/20 f.28, Jan 7, 1588.

${ }^{70}$ See Joanne Paul, 'The Use of Kairos in Renaissance Political Philosophy', Renaissance Quarterly 67.1 (2014): 43-78.

${ }^{71}$ SP 68/3 f.146 , June 261549

${ }^{72}$ SP 70/8 f.122 ${ }^{\mathrm{v}}$, Nov. 10 1559; SP 70/8 f.161 ${ }^{\mathrm{r}}$, Nov. 231559.

${ }^{73}$ SP 70/52 f.44 ${ }^{\text {r }}$, March 31563.

${ }^{74}$ SP 78/2 f.27r, April 21578.

${ }^{75}$ SP 78/2 f.27 , April 21578.

${ }^{76}$ SP 83/8 f.24r , Aug. 91578.

${ }^{77}$ SP 83/8 f.24r, Aug. 91578.

${ }^{78}$ Simonds d'Ewes, 'Journal of the House of Commons: May 1572', in The Journals of All the Parliaments During the Reign of Queen Elizabeth (Shannon, 1682), 205-221.

${ }^{79}$ Cotton Caligula D/I f. $45^{\mathrm{v}}$.

${ }^{80}$ Cotton Caligula D/I f. $46^{\mathrm{r}-\mathrm{v}}$.

${ }^{81}$ Cotton Caligula D/I f. $46^{\mathrm{v}}$.

${ }^{82}$ Cotton Caligula D/I f. $49^{\mathrm{r}}, 49^{\mathrm{v}}$.

${ }^{83}$ Cotton Caligula D/I f. 54v .

${ }^{84}$ Cotton Caligula D/I f. $77^{\mathrm{r}}$.

${ }^{85}$ Cotton Caligula D/I f. $82^{\mathrm{v}}$.

${ }^{86}$ Cotton Caligula D/I f. $84^{\mathrm{r}}$. 
Brief Bibliography

\section{Works Cited}

\section{Primary Sources:}

Botero, Giovanni. Botero: The Reason of State. Edited by Robert Bireley. Cambridge, United Kingdom ; New York, NY: Cambridge University Press, 2017.

Elyot, Sir Thomas. The boke named the gouernour. London: Thomas Berthelet, 1531. STC 7635 .

Machiavelli, Niccolò. The Prince. Edited by Quentin Skinner and Russell Price. Cambridge: Cambridge University Press, 1988.

\section{Secondary Sources:}

Anglo, Sydney. Machiavelli - the First Century: Studies in Enthusiasm, Hostility and Tudor Politics in the Sixteenth Century. Oxford: Oxford University Press. 2005.

Condren, Conal. 'Reason of State and Sovereignty in Early Modern England: A Question of Ideology?’ Parergon 28.2 (2011): 5-27.

Guy, John. 'The Rhetoric of Counsel in Early Modern England.' In Tudor Political Culture, edited by Dale Hoak, 292-310. Cambridge University Press, 1995.

Paul, Joanne. 'Counsel and Command in Anglophone Political Thought, 1485-1651.' PhD. diss., Queen Mary, University of London, 2013.

--. 'Sovereign Council or Counseled Sovereign: The Marian Conciliar Compromise.' In The Birth of a Queen: Essays on the Quincentenary of Mary I, edited by Sarah Duncan and Valerie Schutte, 135-153. New York: Palgrave, 2016.

Rose, Jacqueline. 'Kingship and Counsel in Early Modern England.' The Historical Journal. 54.1 (2011): 47-71.

Viroli, Maurizio. From Politics to Reason of State: The Acquisition and Transformation of the Language of Politics, 1250-1600. Cambridge: Cambridge University Press, 1992. 